\title{
STUDI STABILITAS PERALIHAN SISTEM TENAGA LISTRIK DENGAN METODA EKSPANSI DERET TAYLOR MENGGUNAKAN PERHITUNGAN PROGRAM FORTRAN
}

\author{
Aris Suryadi ${ }^{1}$ \\ ${ }^{1}$ Dosen Tetap Politeknik Enjinering Indorama

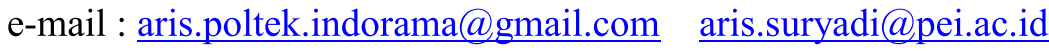

\begin{abstract}
Abstrak : Kestabilan suatu sistem tenaga listrik merupakan masalah yang sangat penting dalam upaya memelihara pengadaan energi listrik yang andal. Analisa sistem tenaga listrik bertujuan untuk melihat kondisi sistem apakah berada pada keadaan stabil atau tidak, setelah mengalami gangguan yang berasal dari dalam sistem maupun dari luar sistem.

Penelitian ini menerapkan Metoda Ekspansi Deret Taylor dengan bantuan dalam perhitungan menggunakan Bahasa Program Fortran, dimana dalam penentuan batas kestabilan sistem tenaga pada ayunan pertama melalui penyelidikan puncak sudut rotor generatorgenerator yang mengalami gangguan-gangguan.

Nilai puncak sudut rotor diselidiki dengan pengamatan akar-akar dari turunan pertama sudut rotor terhadap waktu dari generator-generator dengan menggunakan Ekspansi Deret Taylor. Batas kestabilan yang berkaitan dengan waktu pemutusan kritis merupakan nilai maksimum dari lamanya suatu gangguan, bila paling sedikit terdapat satu akar real positif dari turunan sudut yang bersangkutan.
\end{abstract}

Kata Kunci : sudut rotor, ayunan pertama, waktu pemutusan kritis

Abstract : The stability of the electric power system is a very important issue in efforts to maintain reliable electrical energy supply. Analysis of electric power system aims to see whether the condition of the system is at steady state or not, after experiencing interference that comes from within the system and outside the system.

This research applies Taylor series expansion method to aid in calculations using Fortran Programming Language, in which the delimitation of power system stability on the first swing through the investigation peak rotor angle generators were experiencing disturbances.

The peak value of the rotor angle investigated by observing the roots of the first derivative of the rotor angle with respect to time of the generators by using a Taylor series expansion. Limit of stability with regard to the critical disconnection time is the maximum value of the duration of a disturbance, if there is at least one positive real root of the derivative of the angle concerned.

Keyword : rotor angle, first swing, critical disconnection time.

\section{Pendahuluan}

\subsection{Latar Belakang}

Kestabilan merupakan salah satu parameter yang penting dalam menentukan 
pendekatan dari suatu sistem. Terlebih untuk sistem-sistem yang digunakan selama 24 jam sehari seperti sistem tenaga listrik, yang tentunya di dalam pengoperasiannya selalu dipelihara supply tegangan listrik jala-jala untuk para penggunanya agar tetap berada dalam batas-batas yang aman. Hal ini hanya bisa dilakukan dengan koordinasi design yang baik dari tahap perencanaan sampai pada saat pengoperasiannya.

Masalah stabilitas dalam sistem tenaga listrik adalah menyangkut kemampuan sistem untuk kembali ke kondisi stabil setelah mengalami gangguan.

Di dalam sistem tenaga dibedakan menjadi 3 (tiga) stabilitas [17] :

1. Stabilitas Mantap (steady state stability), menyangkut kemampuan sistem untuk tetap dalam keadaan sinkron stelah adanya perubahan daya relatif lambat.

2. Stabilitas Dinamik (dynamic stability), menyangkut kemampuan sistem untuk tetap dlam keadaan sinkron setelah ayunan pertama rotor sampai sistem mencapai kesetimbangan tetap, baru dimana governor telah mulai bekerja.

3. Stabilitas Peralihan (transient stability), menyangkut kemampuan sistem untuk tetap dalam keadaan sinkron setelah adanya perubahan daya yang cukup besar, seperti akibat terjadinya gangguan hubung singkat.

\subsection{Tujuan}

Tujuan yang dicapai dalam penelitian ini adalah :

1. Mengetahui suatu sistem tenaga listrik stabil atau tidak dengan menentukan terlebih dahulu nilai batas stabilitas.

2. Menentukan lama waktu pemutusan kritis (crital clearing time) terhadap gangguan, terutama gangguan hubung singkat tiga phasa.

3. Batas stabilitas dan waktu pemutusan kritis dikaitkan dengan nilai maksimum lamnya gangguan dari penyelidikan adalah bila paling sedikit satu dari akar-akar turunan pertama sudut rotor adalah positif nyata.

\subsection{Pembatasan Masalah}

Batasan - batasan masalah dalam penelitian ini adalah:

1. Pengaruh-pengaruh governor dan AVR diabaikan, karena dalam waktu singkat kedua peralatan tersebut masih dianggap belum memberikan reaksinya. Sudut rotor $\left(\theta_{1}\right)$ untuk masing-masing generator sama dengan sudut fasa dari tegangan internal generator.

2. Gangguan tiga fasa tidak diperhitungankan. Gangguan tiga fasa yang terjadi di saluran dengan asumsikan saluran tersebut dilepas oleh switching. Untuk saluran tunggal atau ganda pada sistem apabila terjadi gangguan pada salah satu saluran dianggap saluran tersebut dilepas oleh switching. 
3. Dengan adanya pelepasan saluran oleh switching akibat gangguan tiga fasa akan berdampak terganggunya bus, hal ini sebagai indikasi untuk menentukan gangguan pada mesin yang terdekat atau pembangkit.

\subsection{Tinjauan Pustaka}

Adapun penelitian ini didapatkan dari membaca beberapa proposal yang diteliti oleh para ahli diantaranya metoda yang digunakan untuk sistem linear metoda Routh-Hourwitt dengan melihat akar persamaan karakteristik sistem, metoda Root Locus dengan melihat akar persamaan katrakteristik dalam sumbu koordinat komplek.

Selain itu untuk sistem non-linear digunakan metoda Phase Plane dan Describing Functions dengan pendekatan grafis, dan metoda Lyapunov menggunakan pendekatan grafis serta metoda Popov yang mendekati permasalahan dengan penerapan kriteria tertentu pada sistem.[13]

\subsection{Metodologi Penelitian}

Mengamati dan menganalisa dari beberapa jurnal tentang penyelidikan masalah kestabilan peralihan yang kemukakan dengan berbagai metoda dipilihlah metoda ekspansi Deret Taylor. Melakukan penelitian pada sistem PLN Sumbar $150 \mathrm{kV}$ tahun 1997.

\section{Metoda}

\subsection{Survei Data}

Survei dilakukan secara langsung mengumpulkan data yang diperlukan untuk melakukan penelitian pada sistem kelistrikan PLN Sumbar $150 \mathrm{kV}$.

\subsection{Data Hasil Survey}

Table 1. Data Kapasitas Pembangkit Sistem Sumbar. [1]

\begin{tabular}{|c|c|c|c|c|c|c|c|}
\hline NO & PEMBANGKIT & UNIT & $\begin{array}{c}\text { DAYA } \\
(\mathrm{MW})\end{array}$ & $\begin{array}{c}\text { JUMLAH } \\
(\mathrm{MW})\end{array}$ & $\begin{array}{c}\text { MPT } \\
(\mathrm{MW})\end{array}$ & $\begin{array}{c}\text { MPU } \\
(\mathrm{MW})\end{array}$ & $\begin{array}{c}\text { Konstanta } \\
\text { Inersia } \\
\text { M (MJ/MVA) }\end{array}$ \\
\hline 1 & PLTU OMBILIN & 2 & 100.00 & 200.00 & 200.00 & 200.00 & 5.00 \\
\hline 2 & PLTG PAUH LIMO & 3 & 21.35 & 64.05 & 64.05 & 48.00 & 4.00 \\
\hline 3 & PLTA MANINJAU & 4 & 17.00 & 68.00 & 68.00 & 68.00 & 3.00 \\
\hline 4 & PLTA SINGKARAK & 4 & 43.75 & 175.00 & 175.00 & 87.50 & 3.00 \\
\hline
\end{tabular}

Table 2. Data Saluran Transmisi. [1]

\begin{tabular}{|c|c|c|c|c|}
\hline \multirow{2}{*}{$\begin{array}{c}\text { No. } \\
\text { Sal }\end{array}$} & \multicolumn{2}{|c|}{ Nomor Bus } & \multirow{2}{*}{$\begin{array}{c}\text { R } \\
\text { (p.u) }\end{array}$} & X (p.u) \\
\cline { 2 - 4 } & Awal & Akhir & \\
\hline 1 & 1 & 2 & 0.0013 & 0.00456 \\
\hline 2 & 2 & 3 & 0.0144 & 0.05178 \\
\hline
\end{tabular}




\begin{tabular}{|c|c|c|c|c|}
3 & 3 & 4 & 0.0179 & 0.06386 \\
\hline 4 & 4 & 5 & 0.0035 & 0.01255 \\
\hline 5 & 5 & 6 & 0.0177 & 0.06351 \\
\hline 6 & 5 & 11 & 0.0037 & 0.01319 \\
\hline 7 & 6 & 8 & 0.0297 & 0.10685 \\
\hline 8 & 6 & 12 & 0.0045 & 0.02213 \\
\hline 9 & 7 & 8 & 0.0220 & 0.07616 \\
\hline 10 & 7 & 9 & 0.0168 & 0.05803 \\
\hline 11 & 9 & 10 & 0.0138 & 0.04970 \\
\hline 12 & 1 & 4 & 0.0335 & 0.12051 \\
\hline 13 & 1 & 10 & 0.0148 & 0.05330 \\
\hline 14 & 10 & 12 & 0.0274 & 0.08390 \\
\hline 15 & 10 & 13 & 0.0157 & 0.04820 \\
\hline
\end{tabular}

Table 3. Data Bus Pembangkitan dan Pembebanan. [1]

\begin{tabular}{|c|c|c|c|c|c|c|c|}
\hline \multirow[b]{2}{*}{$\begin{array}{l}\text { No. } \\
\text { BUS }\end{array}$} & \multirow[b]{2}{*}{$\begin{array}{l}\text { TIPE } \\
\text { BUS }\end{array}$} & \multirow{2}{*}{$\begin{array}{l}\text { Teg. } \\
\text { BUS } \\
(\mathrm{kV})\end{array}$} & \multirow[b]{2}{*}{$\begin{array}{l}\text { Sudut } \\
(\mathrm{Rad})\end{array}$} & \multicolumn{2}{|c|}{ Pembangkitan } & \multicolumn{2}{|c|}{ Pembebanan } \\
\hline & & & & $\begin{array}{c}\mathrm{Pg} \\
(\mathrm{MW})\end{array}$ & $\begin{array}{c}\text { Qg } \\
\text { (MVAR) }\end{array}$ & $\begin{array}{c}\mathrm{Pb} \\
(\mathrm{MW})\end{array}$ & $\begin{array}{c}\mathrm{Qb} \\
(\mathrm{MVAR})\end{array}$ \\
\hline 1 & SLACK & 151.5000 & 0.0000 & 85.4140 & 49.1523 & 0.0000 & 0.0000 \\
\hline 2 & PQ & 151.3667 & -0.0022 & 0.0000 & 0.0000 & 4.4000 & 2.1100 \\
\hline 3 & PQ & 150.6537 & -0.0150 & 0.0000 & 0.0000 & 14.8000 & 7.1000 \\
\hline 4 & PQ & 150.8582 & -0.0238 & 0.0000 & 0.0000 & 64.8000 & 31.1000 \\
\hline 5 & $\mathrm{PV}$ & 150.5000 & -0.0220 & 40.0000 & 15.0000 & 51.4000 & 24.6700 \\
\hline 6 & PQ & 151.0619 & -0.0121 & 0.0000 & 0.0000 & 47.3000 & 22.7000 \\
\hline 7 & PQ & 150.1765 & -0.0195 & 0.0000 & 0.0000 & 21.8000 & 10.5500 \\
\hline 8 & PV & 151.5000 & -0.0114 & 48.0000 & 20.0000 & 11.8000 & 4.8500 \\
\hline 9 & PQ & 149.3015 & -0.0223 & 0.0000 & 0.0000 & 39.5000 & 18.9600 \\
\hline 10 & PQ & 149.8882 & -0.0143 & 0.0000 & 0.0000 & 17.2000 & 8.2600 \\
\hline 11 & PQ & 151.4440 & -0.0225 & 0.0000 & 0.0000 & 4.6000 & 2.2100 \\
\hline 12 & $\mathrm{PV}$ & 151.5000 & -0.0012 & 120.0000 & 60.0000 & 0.0000 & 0.0000 \\
\hline 13 & PQ & 149.0448 & -0.0201 & 0.0000 & 0.0000 & 14.3000 & 6.8600 \\
\hline
\end{tabular}

\section{HASIL DAN PEMBAHASAN}

\subsection{Representasi Sistem}

Dalam studi kestabilan adalah menentukan apakah rotor mesin yang terganggu dapat kembalike keadaan kerja dengan kecepatan konstan, atau tidak. Hal ini 
berarti kecepatan rotor harus menyimpang dari kecepatan serempak, setidaktidaknya untuk sementara waktu.

Kestabilan sistem daya dapat didefinisikan sebagai sifat sistem yang memungkinkan mesin bergerak serempak dalam sistem untuk memberikan reaksinya terhadap gangguan dalam keadaan kerja normal serta balik kembali ke keadaan semula bila keadaan menjadi normal.

Suatu sistem tenaga dikatakan stabil pada ayunan pertama (first swing stable) semua sudut rotor generator dalam sistem Centre of Angle (COA) pada reference frame akan naik (atau turun) sampai puncak (atau lembah) dimana pergerakan sudut rotor mulai berbalik arah. Sistem tidak stabil pada ayunan pertama bila sudut dari suatu generator naik turunnya secara monoton.[14]

Secara matematis sistem dapat dikatakan stabil pada ayunan pertama jka pertidaksamaan berikut terpenuhi :

$$
\left|\theta_{1}\left(t_{1}\right)+\varepsilon\right|<\left|\theta_{1}\left(t_{1}\right)\right|
$$

Untuk generator dengan $t_{1}$ ( $>$ waktu pemutusan) merupakan waktu tercapainya harga puncak (atau lembah) dari sudut rotor generator ke $-\mathrm{i}$ dan adalah bilangan kecil positif tertentu. Bila sistem stabil pada ayaunan pertama, maka umumnya sistem governor, redaman pada sistem , dan lain sebagainya akan membantu sistem untuk tetap stabil pada ayunan-ayunan berikutnya.

Pada sistem tenaga dengan $\mathrm{n}$ buah mesin, kinerja dinamik tingkat dua dari generator ke-i dalam Centre Of Angle (COA) reference frame dapat dinyatakan dengan persamaan-persamaan diferensial sebagai berikut [8]:

$$
\dot{\theta}=\omega_{i}
$$

Dan :

$$
\dot{\theta}=\frac{\left[P_{i}-P_{e i}-\frac{M_{i}}{M_{T}}-P_{C O A}\right]}{M_{i}}
$$

Dimana :

$$
\begin{aligned}
& P_{i}=P_{m i}-E_{i}^{2} G_{i, j} \\
& M_{T}=\sum_{i=1}^{n} M_{i} \\
& P_{e i}=\sum_{j=1}^{n} C_{i j} \operatorname{Sin} \theta_{i j}+D_{i j} \operatorname{Cos} \theta_{i j} \\
& P_{C O A}=\sum_{i=1}^{n} P_{i}-2 \sum_{i=1}^{n-1} \sum_{j=j+1}^{n} D_{i j} \operatorname{Cos} \theta_{i j} \\
& C_{i j}=E_{i} E_{j} B_{i j} \\
& D_{i j}=E_{i} E_{j} G_{i j}
\end{aligned}
$$

\subsection{Menentukan Sudut Rotor dengan Ekspansi Deret Taylor}

Keadaan sistem saat mengalami gangguan dari mesin ke-i dalam $C O A$ reference frame dapat didekati dengan ekspansi deret Taylor sebagai berikut [8]: 


$$
\theta_{i}(t)=\theta_{i}(0)+\theta_{i}^{(1)} t+\theta_{i}^{(2)} \frac{t^{2}}{2 !}+\theta_{i}^{(3)} \frac{t^{3}}{3 !}+\cdots
$$

Dan :

$$
\omega_{i}(t)=\omega \theta_{i}(0)+\omega_{i}^{(1)} t+\omega_{i}^{(2)} \frac{t^{2}}{2 !}+\omega_{i}^{(3)} \frac{t^{3}}{3 !}+\cdots
$$

Jika gangguan ditiadakan pada saat $t=t_{c l}$ maka sudut rotor setelah gangguan dari generator ke-i dijelaskan dalam bentuk deret Taylor sebagai berikut [8] :

Dengan :

$$
\theta_{i}\left(t_{1}\right)=a_{i 0}+a_{i 1} t_{1}+a_{i 2} t_{1}^{(2)}+a_{i 3} t_{1}^{(3)}+\cdots
$$

$$
\begin{aligned}
& t_{i}=t-t_{c l} \\
& a_{i 0}=\theta_{i}\left(t_{c l}\right) \\
& a_{i 1}=\omega_{i}\left(t_{c l}\right) \\
& a_{i m}=\frac{\theta_{i}^{(m)}}{m !} \quad m=1,2,3, \ldots
\end{aligned}
$$

Koefisien-koefisien a dihitung pada saat $t=t_{c l}$ dengan menggunakan parameterparameter jaringan setelah gangguan.

Koefisien-koefisien a dihitung dengan mencari besaran derivative dari $\theta_{i}$ sebagai berikut [9]:

$$
\begin{aligned}
\theta_{i}^{(2)}= & \frac{1}{M}\left[P_{m}-\sum_{j=1}^{n}\left(C_{i j} \operatorname{Sin} \theta_{i j}+D_{i j} \operatorname{Cos} \theta_{i j}\right)-\frac{M_{i}}{M_{T}} \sum_{k=1}^{n} P_{k}+\cdots+\right. \\
& \left.2 \frac{M_{i}}{M_{k}} \sum_{k=1}^{n-1} \sum_{j=k+1}^{n} D_{k j} \operatorname{Cos} \theta_{k j}\right]
\end{aligned}
$$

Dalam hal ini didefinisikan :

$$
\begin{aligned}
& A_{i j}=\left(C_{i j} \operatorname{Sin} \theta_{i j}+D_{i j} \operatorname{Cos} \theta_{i j}\right) / M_{i} \\
& B_{i j}=\left(-C_{i j} \operatorname{Cos} \theta_{i j}+D_{i j} \operatorname{Sin} \theta_{i j}\right) / M_{i} \\
& F_{i j}=\left(2 \operatorname{Cos} \theta_{i j}\right) / M_{T} \\
& H_{i j}=\left(2 \operatorname{Sin} \theta_{i j}\right) / M_{T}
\end{aligned}
$$

Turunan terhadap waktu dari $\mathrm{A}, \mathrm{B}, \mathrm{F}$ dan $\mathrm{H}$ adalah :

$$
\begin{aligned}
\frac{d A_{i j}}{d t} & =-B_{i j} \theta_{i j}^{(1)} \\
\frac{d B_{i j}}{d t} & =A_{i j} \theta_{i j}^{(1)} \\
\frac{d F_{i j}}{d t} & =-H_{i j} \theta_{i j}^{(1)} \\
\frac{d H_{i j}}{d t} & =F_{i j} \theta_{i j}^{(1)}
\end{aligned}
$$

Turunan kedua atau lebih tinggi dari harga $\theta_{i}^{(m)}$ dapat ditentukan sebagai berikut:

$$
\begin{aligned}
& d_{1}=-\sum_{k=1}^{n-1} \frac{P_{k}}{M_{T}}+\sum_{k=1}^{n-1} \sum_{j=k+1}^{n} F_{k j} \\
& d_{2}=-\sum_{k=1}^{n-1} \sum_{j=k+1}^{n} H_{k j}+\theta_{k j}^{(1)} \\
& d_{3}=-\sum_{k=1}^{n-1}+\sum_{j=k+1}^{n}\left[F_{k j} \theta_{k j}^{(2)}+H_{k j} \theta_{k j}^{(2)}\right]
\end{aligned}
$$




\subsection{Identifikasi Mesin-Mesin yang Mengalami Gangguan Berat}

Jika terjadi gangguan pada sistem, biasanya mesin yang mengalami gangguan berat dan generator-generator inilah yang menentukan ketidakstabilan ayunan pertama maka stabilitas dapat ditentukan dengan meneliti pertidaksamaan (1) terbatas untuk harga puncak sudut rotor dari banyak sistem umumnya terjadi dalam jangka waktu yang sangat pendek setelah gangguan ditiadakan.

Untuk jangka waktu yang relative pendek sudut rotor didapatkan dengan hanya mengambil beberapa suku saja dari deret Taylor pada persamaan (12).

Prosedur untuk identifikasi sejumlah mesin-mesin yang mengalami gangguan berat adalah sebagai berikut :

1. Hitung besaran simpangan $J_{i}=\left|\theta_{i}(t)-\theta_{i}(0)\right|$

Untuk :

$$
\begin{aligned}
i & =1,2,3, \ldots, n \\
\theta_{i}(t) & =\text { sudut gangguan } \\
\theta_{i}(0) & =\text { sudut sebelum gangguan }
\end{aligned}
$$

Besaran sudut gangguan $\theta_{i}(t)$ dihitung dengan menggunakan ekspansi deret Taylor

2. Dapatkan besaran simpangan $\left(J_{k}^{*}\right)$

3. Tentukan mesin ke-j terhadap salah satu yang mengalami gangguan berat.

$$
J_{j} / J_{k}^{*}>\sigma \quad ; \sigma<3
$$

Nilai $\sigma$ pada beberapa studi $=2,98$

\subsection{Penentuan Stabilitas}

Keberadaan nilai puncak sudut-sudut rotor setelah terjadi gangguan dapat dihitung dengan mengamati akar-akar dari turunan kedua terhadap waktu dari sudut-sudut rotor tersebut.

Pernyataan tersebut di atas dapat dilihat pada persamaan sebagai berikut [8]:

$$
\theta\left(t_{1}\right)=a_{0}+a_{1} t_{1}+a_{2} t_{1}^{(2)}+a_{3} t_{1}^{(3)}+\cdots
$$

Turunan waktu dari persamaan ini bila dibuat sama dengan 0 (nol) maka dapat dituliskan menjadi :

$$
\frac{d \theta\left(t_{1}\right)}{d t}=2 a_{1}+2 a_{2} t_{1}+3 a_{3} t_{1}^{2}=0
$$

Jika nilai puncak sudut rotor $\left(t_{p}\right)$ sebesar :

$$
t_{p}=\frac{-2 a_{2} \pm \sqrt{\left(4 a_{2}^{2}-12 a_{1} a_{3}\right)}}{6 a_{3}}
$$

Jika akar-akar tersebut mempunyai bilangan negatif atau komplek untuk generator yang mengalami gangguan berat maka sistem masih dianggap tidak stabil.

Jika akar-akar tersebut mempunyai bilangan positif untuk generator yang mengalami gangguan berat maka sistem masih dianggap stabil. 


\subsection{Algoritma Penentuan Waktu Pemutusan Kritis}

Dalam menentukan waktu pemutusan kritis pada suatu sistem, menggunakan metoda langsung dengan algoritma sebagai berikut :

1. Bentuk reduksi matrik selama gangguan.

2. Hitung turunan kedua dan ketiga dari $\theta_{i}$.

3. Hitung harga pada $t=t_{c l}$ mulai dari awal, diteruskan langkah demi langkah, kemudian hitung pula harga $\omega_{i}=\theta_{i}^{(1)}$ pada $t=t_{c l}$ mulai dari awal diteruskan langkah demi langkah.

4. Tetapkan harga $\theta_{i}$ dan $\omega_{i}$ pada $t=t_{c l}$ sebagai harga mula.

5. Bentuk reduksi matrik setelah gangguan.

6. Hitung turunan kedua dan ketiga.

7. Hitung $\omega_{i}=\theta_{i}^{(1)}$ pada $t_{i}=t_{c l}$

8. Selidiki apakah memiliki akar real positif.

9. Jika "Ya" berarti stabil, naikkan $t_{c l}$ ke-3 dengan $t=t_{c l \text { baru }}=t_{c l \text { lama }}+$ $\Delta t$, jika tidak ada berarti sistem tidak stabil kemudian cetak waktu pemutusan kritis.

\subsection{Tampilan Monitor Untuk 2(dua) Saluran di lepas :}

\section{Satu pada saluran tunggal dan dua pada saluran ganda}

Apakah ada admitansi Shunt $[\mathrm{y} / \mathrm{t}] / \mathrm{y}$

Jumlah Saluran yang di lepas : 2

Saluran yang di lepas [i,j] ? 1,2

Saluran yang di lepas [I,j] ? 5,6

Merupakan Rel Ganda

Zona di lepas

1. Satu Saluran

2. Dua Saluran

Pilihan : 2

Lokasi Bus Terganggu : 2

Lokasi Bus Terganggu : 11

Lokasi Bus Terganggu : 13

Sistem Tidak Stabil

Waktu P_Kritis Mesin 1: .00 second

Waktu P_Kritis Mesin 1: 1.80 second

Waktu P_Kritis Mesin 1: 2.00 second

Waktu P_Kritis Mesin 5: 1.00 second

Waktu P Kritis Mesin 5: 1.20 second

Waktu P_Kritis Mesin 8: 1.60 second

Waktu P_Kritis Mesin 8 : 1.80 second 
Waktu P_Kritis Mesin 12: 1.60 second Waktu P_Kritis Mesin 12 : 1.80 second

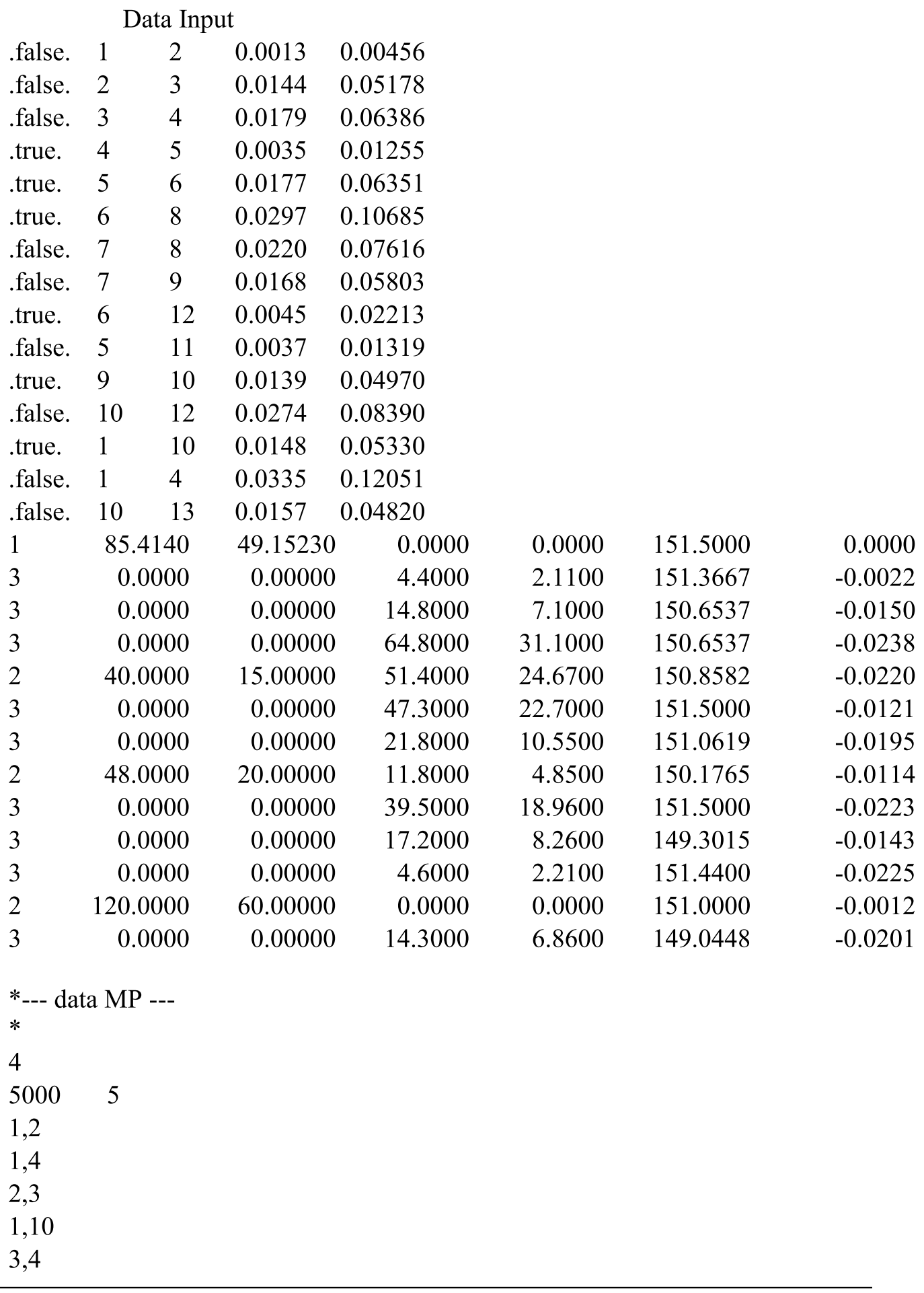


$4000 \quad 3$

5,11

5,4

5,6

$3000 \quad 3$

8,6

8,7

7,9

$3000 \quad 4$

12,6

12,10

10,13

9,10

Tabel 4. Hasil Perhitungan Sudut Rotor dan Kecepatan Rotor Pembangkit Ombilin (Bus 1) pada Gangguan di Simpang Haru (Bus 11)

\begin{tabular}{cccc}
$\begin{array}{c}\text { Mesin } \\
\text { (Bus) }\end{array}$ & $\begin{array}{c}\mathrm{t} \\
(\mathrm{second})\end{array}$ & $\begin{array}{c}\text { Sud.Rotor } \\
(\mathrm{rad})\end{array}$ & $\begin{array}{c}\text { Kec. Rotor } \\
(\mathrm{rad} / \mathrm{s})\end{array}$ \\
1 & 0.00 & 0.0000 & -0.0333 \\
1 & 0.20 & -0.0105 & -0.0720 \\
1 & 0.40 & -0.0288 & -0.1108 \\
1 & 0.60 & -0.0548 & -0.1497 \\
1 & 0.80 & -0.0887 & -0.1888 \\
1 & 1.00 & -0.1303 & -0.2280 \\
1 & 1.20 & -0.1798 & -0.2673 \\
1 & 1.40 & -0.2371 & -0.3068 \\
1 & 1.60 & -0.3023 & -0.3465 \\
1 & 1.80 & -0.3753 & -0.3863 \\
1 & 2.00 & -0.4563 & -0.4263 \\
\hline & &
\end{tabular}

Tabel 5. Hasil Perhitungan Sudut Rotor dan Kecepatan Rotor Pembangkit Pauh Limo (Bus 5) pada Gangguan di Simpang Haru (Bus 11) 


\begin{tabular}{cccc}
$\begin{array}{c}\text { Mesin } \\
(\text { Bus })\end{array}$ & $\begin{array}{c}\mathrm{t} \\
(\text { second })\end{array}$ & $\begin{array}{c}\text { Sud.Rotor } \\
(\mathrm{rad})\end{array}$ & $\begin{array}{c}\text { Kec. Rotor } \\
(\mathrm{rad} / \mathrm{s})\end{array}$ \\
\hline 5 & 0.00 & 0.0000 & -0.3583 \\
5 & 0.20 & -0.0105 & -0.3686 \\
5 & 0.40 & -0.0288 & -0.3793 \\
5 & 0.60 & -0.0548 & -0.3909 \\
5 & 0.80 & -0.0887 & -0.4037 \\
5 & 1.00 & -0.1303 & -0.4182 \\
5 & 1.20 & -0.1798 & -0.4348 \\
5 & 1.40 & -0.2371 & -0.4537 \\
5 & 1.60 & -0.3023 & -0.4754 \\
5 & 1.80 & -0.3753 & -0.5003 \\
5 & 2.00 & -0.4563 & -0.5288 \\
---------
\end{tabular}

Tabel 6. Hasil Perhitungan Sudut Rotor dan Kecepatan Rotor Pembangkit Maninjau (Bus 1) pada Gangguan di Simpang Haru (Bus 11)

\begin{tabular}{cccc}
$\begin{array}{c}\text { Mesin } \\
\text { (Bus) }\end{array}$ & $\begin{array}{c}\mathrm{t} \\
(\mathrm{second})\end{array}$ & $\begin{array}{c}\text { Sud.Rotor } \\
(\mathrm{rad})\end{array}$ & $\begin{array}{c}\text { Kec. } \\
\text { Rotor } \\
(\mathrm{rad} / \mathrm{s})\end{array}$ \\
\hline 8 & 0.00 & 0.0000 & -0.0886 \\
8 & 0.20 & -0.0105 & -0.1259 \\
8 & 0.40 & -0.0288 & -0.1636 \\
8 & 0.60 & -0.0548 & -0.2016 \\
8 & 0.80 & -0.0887 & -0.2400 \\
8 & 1.00 & -0.1303 & -0.2788 \\
8 & 1.20 & -0.1798 & -0.3181 \\
8 & 1.40 & -0.2371 & -0.3578 \\
8 & 1.60 & -0.3023 & -0.3979 \\
8 & 1.80 & -0.3753 & -0.4386 \\
8 & 2.00 & -0.4563 & -0.4797
\end{tabular}




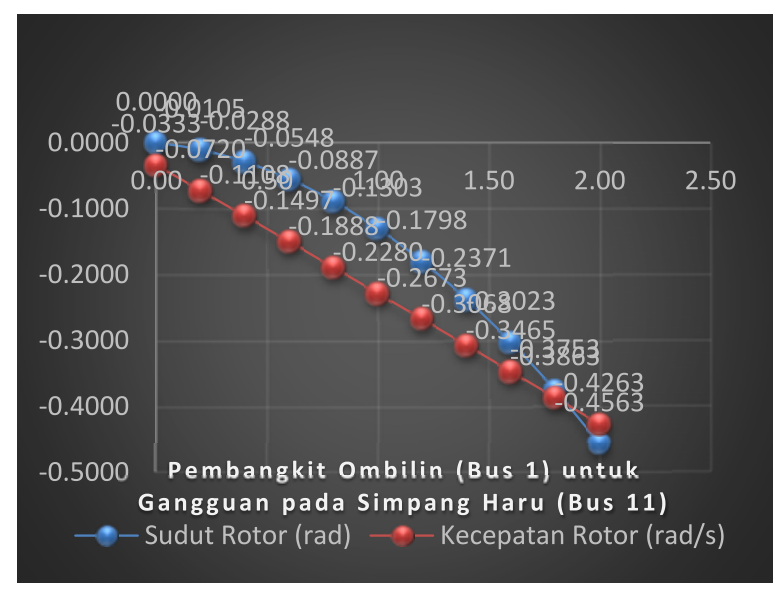

Gambar 1. Pembangkit Ombilin (Bus 1) untuk Gangguan pada Simpang Haru (Bus 11)

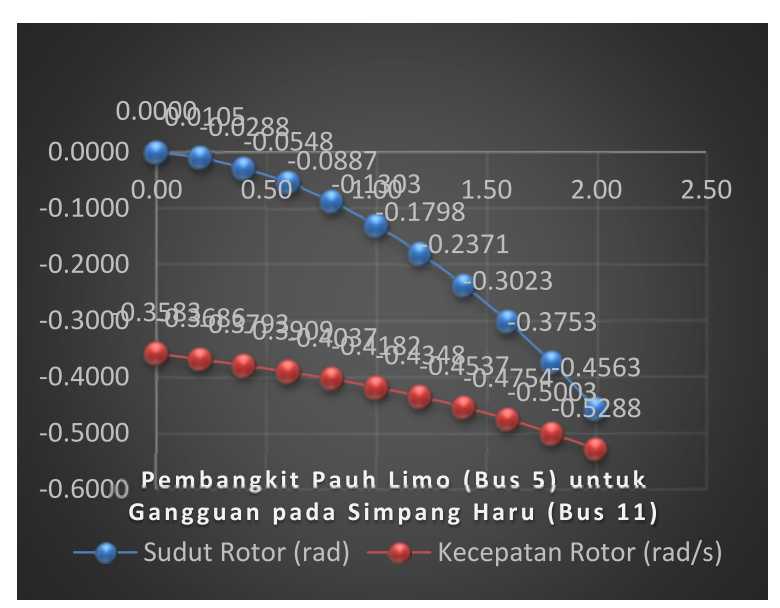

Gambar 2. Pembangkit Pauh Limo (Bus 5) untuk Gangguan pada Simpang Haru (Bus 11) 


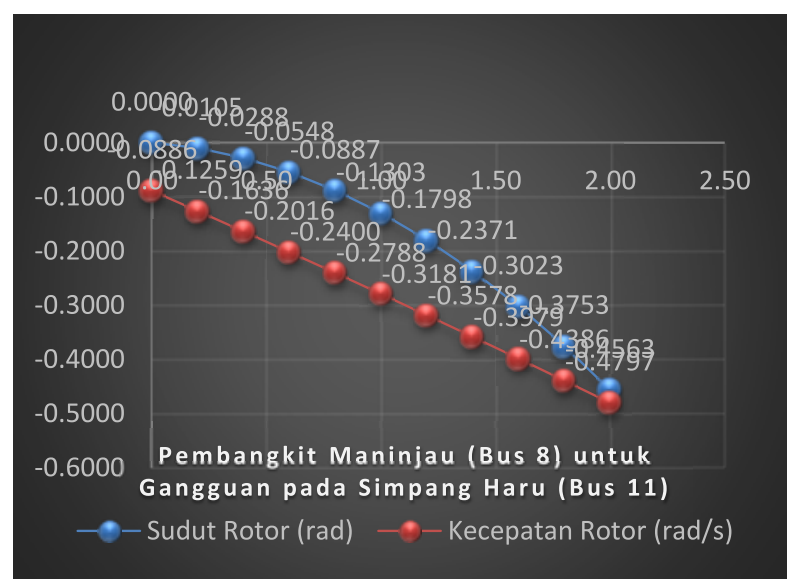

Gambar 3. Pembangkit Maninjau (Bus 8) untuk

Gangguan pada Simpang Haru (Bus 11)

\section{Kesimpulan}

Hasil penelitian dan analisa terhadap berbagai pengujian yang telah dilakukan dapat ditarik kesimpulan sebagai berikut :

1. Nilai sudut rotor diselidiki sampai turunan ke empat terhadap waktu dari generator dengan menggunakan Ekspansi Deret Taylor, hal ini tentunya akan didapatkan nilai waktu pemutusan kritis yang akurat.

2. Metoda yang diterapkan pada penelitian ini dengan melihat saluran yang dilepas dan lokasi bus yang terganggu akan didapatkan lokasi pembangkit (generator yang terganggu) yang paling terdekat dengan lokasi bus yang terganggu.

3. Untuk program yang diterapkan pada sistem jaringan transmisi dilakukan pemutusan 2 (dua) saluran yaitu pada Bus 1-2 dan Bus 5-6, maka didapatkan Bus yang terganggu pada Bus 2, Bus 11 dan Bus 13. Hal ini akan mengakibatkan terganggunya pembangkit yang terdekat yaitu pada Bus 1 (Ombilin), Bus 5 (Pauh Limo), dan Bus 12 (Singkarak). Adapun untuk pembangkit Maninjau yang terletak pada Bus 8 masih dianggap stabil namun untuk keseluruh sistem Sumbar $150 \mathrm{kV}$ dianggap tidak stabil.

\section{Daftar Pustaka}

[1] Anizar Indriani, “ Metode Newton_Raphson Yang Dimodifikasi Untuk Studi Aliran Daya “, Tugas Akhir, Jurusan Teknik Elektro, Universitas Bung Hatta, Padang, 1997.

[2] C-T Liu and T-S Yeh, " Paralel Simulasi of Industrial Power System Transients By an inherent Paralel Algorithm ", Elsevier Sciense Ltd, Printed in Great Britain, Paper : No. 7 pp. 437-443, 1996 
[3] D Handali dan RJ Pamuntjak, "Kalkulus Perubah Banyak ', Penerbit ITB Bandung, Bandung, 1979.

[4] EPRI EL-456 (Research Project 763), “ Development of Dynamic Equivalent for Transient Stability Studies" , Electric Power Reasearch Institute, California, 1977.

[5] E Bompard, E Carpaneto, G Chicco and R Napoli, "A dynamic Interpretation of The Load-Flow Jacobian Singulary for Voltage Stability Analysis", Elsevier Sciense Ltd, Printed in Great Britain, Paper : No. 7 pp. 437-443, 1996.

[6] Francisco P Demello and Charles Concordia, "Concept of Synchoronous Machine Stability as Affected by Excutation Control”, IEEE Transactions On Power Apparatus and Systems, Paper :P Vol Pas 88, No.4, April, 1996.

[7] Hutahaen, "Kalkulus Differensial dan Integral “, Gramedia, PT, Jakarta, 1981.

[8] Haque. MH and Rahim A.H.M.A, "Determination of First Swing Stability Limit of Multimachine Power System Through Taylor Series Expantion", IEE-Praceeding, Paper : Vol.136. pt.c. No.6, November 1989.

[9] Haque. MH and Rahim A.H.M.A, "An Efficient Method of Identifying Coherent Generators Using Taylor Series Expantion", IEE-Transaction on Power Systems, Paper : Vol.3. No.6, August 1988.

[10] Irmayati, "Studi Stabilitas Sistem Daya pada

[11] Gangguan 3 fasa dengan Metode Rungge-Kutta", Tugas Akhir, Jurusan Teknik Elektro, Universitas Bung Hatta, Padang, 1997.

[12] Jogiyanto, "Teori dan Aplikasi Komputer bahasa Fortran", Penerbit Andi Offset, Jakarta, 1989.

[13] KR Padiyar and SS Rao, "Dynamic Analysis of Small Signal Voltage Instability Decoupled from Angle Instability", Elsevier Sceince Ltd, Printed in Great Britain, Paper : No.7 pp.445-4452, 1996.

[14] Mas Eka Sandra Utama dan RJ. Widodo,"Analisis Kestabilan Sistem Tenaga Listrik Menggunakan Metoda Lyapunov", Makalah ITB Bandung, Bandung, 1993.

[15] Pai MA, "Computer Techniques in Power System Analysis", tata McGraw-Hill Publishing Company Limited, New Delhi, 1989.

[16] PLN, PT (persero) KITLUR SUMBAGSEL, Unit Pengatur Beban Sistem Sumbar-Riau, "Evaluasi Operasi Sistem Tenaga Listrik Sumbar-Riau, April, 1999.

[17] S Liu, XP Wang and QZ Yu, "Hybrid Transient Stability Analysis Using Structure Preserving Model", Electric Power and Energy Systems, Elsevier Sciense Ltd, Printed in Great Britain, Paper : Vol.18. No.6, pp. 347-352, 1996.

[18] WD. Stevenson, Jr, “Analisi Sistem Tenaga LIstrik”, Erlangga, 1993.

[19] Wallach Y,"Calculation and Program For Power Network",Printice-Hall, Englewood Cliffs, New Jersey 076321, 1986. 